Supplement of Adv. Geosci., 45, 281-287, 2018

https://doi.org/10.5194/adgeo-45-281-2018-supplement

(C) Author(s) 2018. This work is distributed under

the Creative Commons Attribution 4.0 License.

(c) (1)

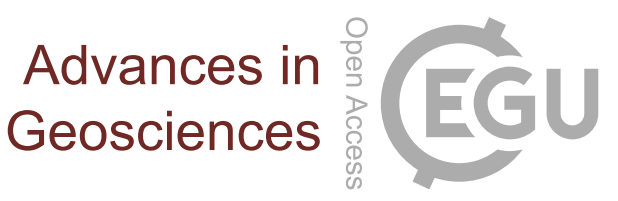

Supplement of

\title{
Outcrop analogue study to determine reservoir properties of the Los Humeros and Acoculco geothermal fields, Mexico
}

Leandra M. Weydt et al.

Correspondence to: Leandra M. Weydt (weydt@geo.tu-darmstadt.de)

The copyright of individual parts of the supplement might differ from the CC BY 4.0 License. 
Sampling campaign and petrophysical rock properties 
Table S1: Petrophysical properties of the outcrop samples at dry conditions

\begin{tabular}{|c|c|c|c|c|c|c|c|c|c|c|c|c|}
\hline Parameters & $\rho_{\mathrm{P}}$ & $\rho_{B}$ & $\phi$ & $\mathbf{K}$ & $\lambda$ & $\alpha$ & $V_{P}$ & $\mathbf{V}_{\mathrm{s}}$ & $E_{\text {dyn }}$ & G & $\rho a$ & $X$ \\
\hline Unit & {$\left[\mathrm{g} \mathrm{cm}^{-3}\right]$} & {$\left[\mathrm{g} \mathrm{cm}^{-3}\right]$} & [\%] & {$\left[\mathrm{m}^{2}\right]$} & {$\left[\mathrm{W} \mathrm{m} \mathrm{K}^{-1} \mathrm{~K}^{-1}\right]$} & {$\left[10^{-6} \mathrm{~m}^{2} \mathrm{~s}^{-1}\right]$} & {$\left[\mathrm{m} \mathrm{s}^{-1}\right]$} & {$\left[\mathrm{m} \mathrm{s}^{-1}\right]$} & {$\left[\mathrm{N} \mathrm{mm}^{-2}\right]$} & {$\left[\mathrm{N} \mathrm{mm}^{-2}\right]$} & {$[\Omega \mathrm{m}]$} & {$\left[10^{-8} \mathrm{~m}^{3} \mathrm{~kg}^{-1}\right]$} \\
\hline \multicolumn{13}{|c|}{ Post-caldera Volcanism } \\
\hline Basalt lava (LH) & $\begin{array}{c}2.49(6) \\
\pm 0.10\end{array}$ & $\begin{array}{l}2.14(6) \\
\pm 0.05\end{array}$ & $\begin{array}{c}14.31(6) \\
\pm 4.51\end{array}$ & $\begin{array}{c}1.29 \mathrm{E}-15(6) \\
\pm 2.67 \mathrm{E}-15\end{array}$ & $0.97(1)$ & $0.56(1)$ & $\begin{array}{c}4146(6) \\
\pm 658\end{array}$ & $\begin{array}{c}2263(6) \\
\pm 448\end{array}$ & $\begin{array}{c}28768(6) \\
\pm 10009\end{array}$ & $\begin{array}{c}11281(6) \\
\pm 4166\end{array}$ & - & - \\
\hline $\begin{array}{l}\text { Ash fall } \\
\text { deposits (LH) }\end{array}$ & $\begin{array}{c}2.34(5) \\
\pm 0.03 \\
\end{array}$ & $\begin{array}{c}1.17(5) \\
\pm 0.03 \\
\end{array}$ & $\begin{array}{c}50.01(5) \\
\pm 1.12 \\
\end{array}$ & $\begin{array}{c}1.29 \mathrm{E}-14(5) \\
\pm 2.79 \mathrm{E}-15\end{array}$ & $\begin{array}{l}0.31(5) \\
\pm 0.01\end{array}$ & $\begin{array}{c}0.63(5) \\
\pm 0.01 \\
\end{array}$ & $\begin{array}{c}1938(4) \\
\pm 240\end{array}$ & $\begin{array}{c}1286(4) \\
\pm 169\end{array}$ & $\begin{array}{c}4170(4) \\
\pm 1125 \\
\end{array}$ & $\begin{array}{c}1961(4) \\
\pm 527\end{array}$ & - & - \\
\hline Rhyolite (AC) & $2.53(1)$ & $\begin{array}{c}2.18(2) \\
\pm 0.06 \\
\end{array}$ & $\begin{array}{l}4.75(2) \\
\pm 6.48 \\
\end{array}$ & - & $0.97(1)$ & - & $\begin{array}{c}3166(1) \\
\pm 118 \\
\end{array}$ & $\begin{array}{c}1845 \text { (1) } \\
\pm 24 \\
\end{array}$ & $18759(1)$ & $7545(1)$ & $\begin{array}{c}13715 \text { (1) } \\
\pm 1245 \\
\end{array}$ & - \\
\hline \multicolumn{13}{|l|}{ Caldera volcanism } \\
\hline Ignimbrite (LH) & $\begin{array}{c}2.47(10) \\
\pm 0.01\end{array}$ & $\begin{array}{c}1.31(10) \\
\pm 0.02\end{array}$ & $\begin{array}{c}47.07(10) \\
\pm 0.87\end{array}$ & $\begin{array}{c}6.79 \mathrm{E}-13(10) \\
\pm 1.59 \mathrm{E}-13\end{array}$ & $\begin{array}{c}0.47(10) \\
\pm 0.02\end{array}$ & $\begin{array}{c}0.50(10) \\
\pm 0.01\end{array}$ & $\begin{array}{l}2061(10) \\
\pm 105\end{array}$ & $\begin{array}{l}1292(10) \\
\pm 106\end{array}$ & $\begin{array}{l}5091(10) \\
\pm 667\end{array}$ & $\begin{array}{l}2193(10) \\
\pm 357\end{array}$ & - & - \\
\hline Pyroclastics (AC) & $\begin{array}{c}2.68(15) \\
\pm 0.02\end{array}$ & $\begin{array}{c}2.33(15) \\
\pm 0.05\end{array}$ & $\begin{array}{c}11.48(15) \\
\pm 4.82\end{array}$ & $\begin{array}{c}3.09 \mathrm{E}-17(12) \\
\pm 3.24 \mathrm{E}-17\end{array}$ & $\begin{array}{c}1.67(13) \\
\pm 0.18\end{array}$ & $\begin{array}{l}0.92(11) \\
\pm 0.05\end{array}$ & $\begin{array}{c}2530(13) \\
\pm 471\end{array}$ & $\begin{array}{c}1991(13) \\
\pm 361\end{array}$ & $\begin{array}{c}24436(13) \\
\pm 8700\end{array}$ & $\begin{array}{c}9742(13) \\
\pm 4214\end{array}$ & $\begin{array}{c}25610(2) \\
\pm 1172\end{array}$ & $\begin{array}{c}193.70(3) \\
\pm 60.82\end{array}$ \\
\hline \multicolumn{13}{|c|}{ Pre-caldera volcanism } \\
\hline Andesite (LH) & $\begin{array}{c}2.68(83) \\
\pm 0.23\end{array}$ & $\begin{array}{c}2.37(72) \\
\pm 0.28 \\
\end{array}$ & $\begin{array}{c}6.58(16) \\
\pm 5.11 \\
\end{array}$ & $\begin{array}{c}2.38 \mathrm{E}-15 \text { (72) } \\
\pm 1.47 \mathrm{E}-15\end{array}$ & $\begin{array}{c}1.33(24) \\
\pm 0.34\end{array}$ & $\begin{array}{c}0.73(24) \\
\pm 0.17\end{array}$ & $\begin{array}{c}3452(15) \\
\pm 963\end{array}$ & $\begin{array}{c}1951 \text { (15) } \\
\pm 521\end{array}$ & $\begin{array}{c}24298(15) \\
\pm 13832\end{array}$ & $\begin{array}{c}9589(15) \\
\pm 5311 \\
\end{array}$ & - & - \\
\hline Andesite (AC) & $\begin{array}{c}2.55(7) \\
\pm 0.06\end{array}$ & $\begin{array}{c}2.27(9) \\
\pm 0.16\end{array}$ & $\begin{array}{c}12.11(3) \\
\pm 9.4\end{array}$ & $\begin{array}{c}1.41 \mathrm{E}-16(6) \\
\pm 3.45 \mathrm{E}-16\end{array}$ & $\begin{array}{l}1.07(3) \\
\pm 0.05\end{array}$ & $\begin{array}{c}0.68(3) \\
\pm 0.01\end{array}$ & $\begin{array}{c}3974(9) \\
\pm 633\end{array}$ & $\begin{array}{c}2262(9) \\
\pm 342\end{array}$ & $\begin{array}{c}30187(9) \\
\pm 11298\end{array}$ & $\begin{array}{l}9788(4) \\
\pm 2836\end{array}$ & - & - \\
\hline \multicolumn{13}{|c|}{ Basement \& Intrusive rocks } \\
\hline Limestone (LH) & $\begin{array}{c}2.69(13) \\
\pm 0.02\end{array}$ & $\begin{array}{c}2.64(10) \\
\pm 0.03\end{array}$ & $\begin{array}{c}2.08(10) \\
\pm 1.24\end{array}$ & $<1 \mathrm{E}-18(8)$ & $\begin{array}{c}2.94(11) \\
\pm 0,11\end{array}$ & $\begin{array}{c}1.24(10) \\
\pm 0.17\end{array}$ & $\begin{array}{c}6907(10) \\
\pm 989\end{array}$ & $\begin{array}{l}3502(10) \\
\pm 472\end{array}$ & $\begin{array}{c}86785(10) \\
\pm 20948\end{array}$ & $\begin{array}{c}32817(10) \\
\pm 8071\end{array}$ & - & - \\
\hline Limestone (AC) & $\begin{array}{c}2.68(28) \\
\pm 0.03\end{array}$ & $\begin{array}{c}2.65(23) \\
\pm 0.08\end{array}$ & $\begin{array}{c}0.96(22) \\
\pm 0.81\end{array}$ & $\begin{array}{c}1.46 \mathrm{E}-16(4) \\
\pm 2.74 \mathrm{E}-16\end{array}$ & $\begin{array}{c}2.88(20) \\
\pm 0,39\end{array}$ & $\begin{array}{c}1.63(14) \\
\pm 0.19\end{array}$ & $\begin{array}{c}6385(18) \\
\pm 982 \\
\end{array}$ & $\begin{array}{l}2998(18) \\
\pm 552\end{array}$ & $\begin{array}{c}65865(22) \\
\pm 20731 \\
\end{array}$ & $\begin{array}{c}24837(18) \\
\pm 9223\end{array}$ & $\begin{array}{c}19331(4) \\
\pm 6820\end{array}$ & $\begin{array}{l}0,85(5) \\
\pm 0.42\end{array}$ \\
\hline Chert (LH) & $\begin{array}{l}2.63(2) \\
\pm 0.002\end{array}$ & $\begin{array}{c}2.59(2) \pm \\
0.01\end{array}$ & $\begin{array}{l}1.73(2) \\
\pm 0.45\end{array}$ & $\begin{array}{c}3.32 \mathrm{E}-16(2) \\
\pm 3.79 \mathrm{E}-16\end{array}$ & $\begin{array}{l}4.21(2) \\
\pm 0.01\end{array}$ & $\begin{array}{c}2.22(2) \\
\pm 0.09\end{array}$ & $\begin{array}{c}5018(2) \\
\pm 119\end{array}$ & $\begin{array}{c}2495(2) \\
\pm 463\end{array}$ & $\begin{array}{c}43718(2) \\
\pm 16581\end{array}$ & $\begin{array}{c}16358(2) \\
\pm 5920\end{array}$ & - & - \\
\hline $\operatorname{Marl}(A C)$ & $2.66(1)$ & $2.505(1)$ & $6.05(1)$ & - & $1.69(1)$ & $1.48(1)$ & $1411(1)$ & $454(1)$ & $1490(1)$ & $516(1)$ & - & - \\
\hline Argillite (LM) & $\begin{array}{c}2.69(6) \\
\pm 0.01\end{array}$ & $\begin{array}{l}2.65(6) \\
\pm 0.03\end{array}$ & $\begin{array}{l}1.52(6) \\
\pm 0.73\end{array}$ & - & $\begin{array}{l}2.32(5) \\
\pm 0.79\end{array}$ & $\begin{array}{c}1.33(5) \\
\pm 0.18\end{array}$ & $\begin{array}{c}2833(5) \\
\pm 1811\end{array}$ & $\begin{array}{c}932(5) \\
\pm 326\end{array}$ & $\begin{array}{l}6645(4) \\
\pm 4176\end{array}$ & $\begin{array}{l}2515(4) \\
\pm 1650\end{array}$ & - & - \\
\hline Marble (LM) & $\begin{array}{c}2.69(3) \\
\pm 0.03\end{array}$ & $\begin{array}{l}2.65(13) \\
\pm 0.04\end{array}$ & $\begin{array}{c}0.56(13) \\
\pm 0.22\end{array}$ & $<1 \mathrm{E}-18(1)$ & $\begin{array}{l}2.71(2) \\
\pm 0.29\end{array}$ & $1.03(1)$ & $\begin{array}{c}5256(12) \\
\pm 539\end{array}$ & $\begin{array}{l}2892(12) \\
\pm 335\end{array}$ & $\begin{array}{c}56315(12) \\
\pm 10880\end{array}$ & $\begin{array}{l}22038(12) \\
\pm 4363\end{array}$ & $\begin{array}{c}19930(11) \\
\pm 6431\end{array}$ & - \\
\hline Granodiorite (LM) & $\begin{array}{c}2.67(6) \\
\pm 0.02\end{array}$ & $\begin{array}{c}2.56(6) \\
\pm 0.04\end{array}$ & $\begin{array}{l}3.02(6) \\
\pm 1.09\end{array}$ & $\begin{array}{c}7,13 \mathrm{E}-18(6) \\
\pm 1.5 \mathrm{E}-17\end{array}$ & $\begin{array}{l}1.84(6) \\
\pm 0.08\end{array}$ & $\begin{array}{l}0.96(6) \\
\pm 0.06\end{array}$ & $\begin{array}{c}4650(6) \\
\pm 900\end{array}$ & $\begin{array}{c}2366(6) \\
\pm 152\end{array}$ & $\begin{array}{c}38129(6) \\
\pm 7517\end{array}$ & $\begin{array}{c}14557(6) \\
\pm 1996\end{array}$ & - & - \\
\hline Skarn (LM) & $\begin{array}{c}3.38(17) \\
\pm 0.38\end{array}$ & $\begin{array}{c}3.13(18) \\
\pm 0.48\end{array}$ & $\begin{array}{c}6.97(16) \\
\pm 4.28\end{array}$ & $\begin{array}{c}2.24 \mathrm{E}-16(14) \\
\pm 4.31 \mathrm{E}-16\end{array}$ & $\begin{array}{c}3.77(17) \\
\pm 0.54\end{array}$ & $\begin{array}{c}1.61(14) \\
\pm 0.28\end{array}$ & $\begin{array}{c}5695(16) \\
\pm 1088\end{array}$ & $\begin{array}{l}2920(16) \\
\pm 583\end{array}$ & $\begin{array}{c}73804(16) \\
\pm 33247\end{array}$ & $\begin{array}{c}28534(16) \\
\pm 12984\end{array}$ & $\begin{array}{l}25610(2) \\
\pm 1172\end{array}$ & $\begin{array}{c}46,30(2) \\
\pm 35.09\end{array}$ \\
\hline
\end{tabular}

$\pm=$ standard deviation, ()$=$ number of analyzed plugs, $A C=$ Acoculco, $\mathrm{LH}=$ Los Humeros, $\mathrm{LM}=$ Las Minas

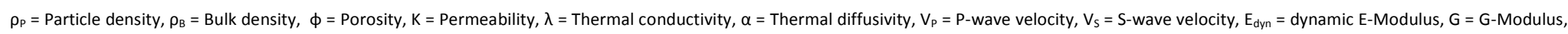

$\rho_{\mathrm{a}}=$ electric resistivity, $\mathrm{X}=$ magnetic susceptibility 


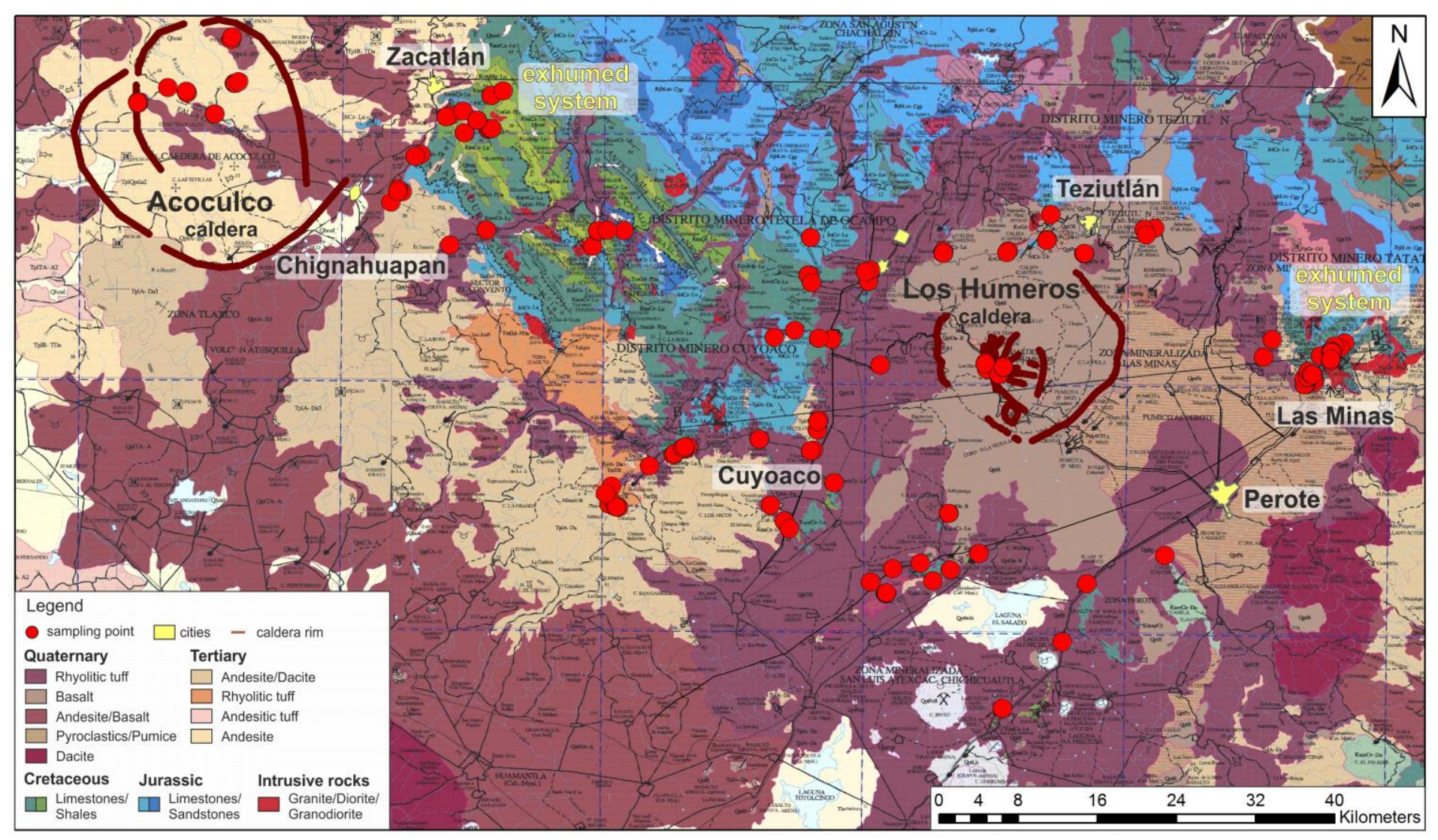

Figure S1: Overview of the study area and sampling locations (SGM, 2002a and b). 

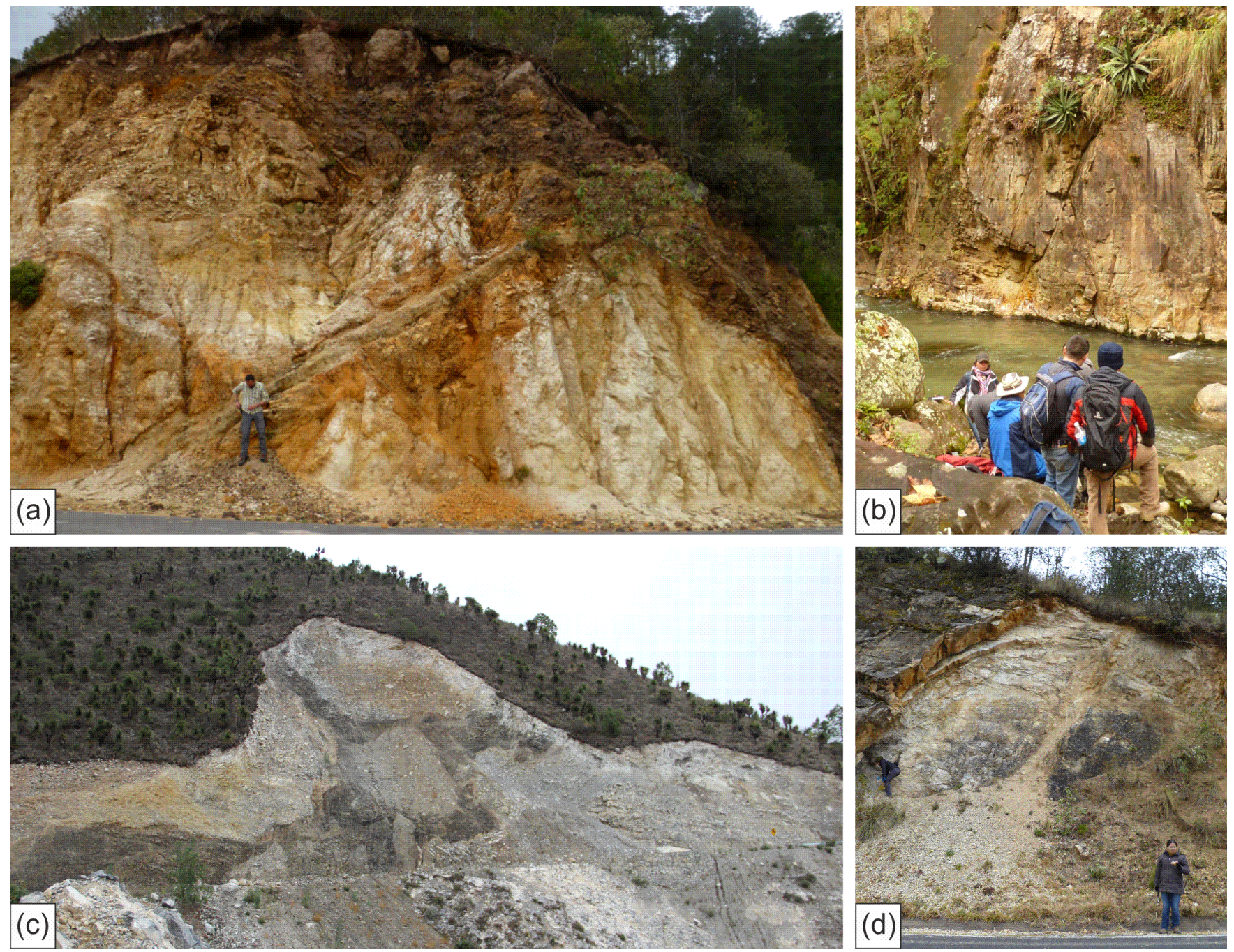

Figure S2: (a) Intensively hydrothermally altered andesitic/basaltic lava cut by an altered dyke about $35 \mathrm{~km}$ west of the Los Humeros caldera. (b) Granitic intrusive body in the Las Minas area. (c) Basaltic dykes intruding the Cretaceous limestones about $30 \mathrm{~km}$ west of the Los Humeros caldera. (d) Dyke -limestone contact west of the Los Humeros caldera. 


\section{Complementary work within milestone 2 - reservoir characterization}

\section{Complementary field work}

Complementary to the investigation of the main fault zones and possible fluid pathways in the study area, detailed scan line measurements have been carried out on selected outcrops in the Las Minas and Acoculco areas to understand fracture-fault

5 interactions and to identify representative fracture patterns for parameterization of the geomechanical models.

Furthermore, shallow geophysical surveys, including electric tomography and ultra sonic wave velocity in the outcrops, aim to characterize the variations of rock mechanical behaviour around brittle deformation-zones from the intact rock to the damage zone and to the shear zone. This approach provides a detailed geomechanical description of the transition zones in close proximity to main fault zones and allows comparison with data from hyperspectral scanning. The results will be

10 correlated with data from laboratory measurements measured on samples taken directly along the shallow geophysical experiments. First results are shown in Fig. 6.

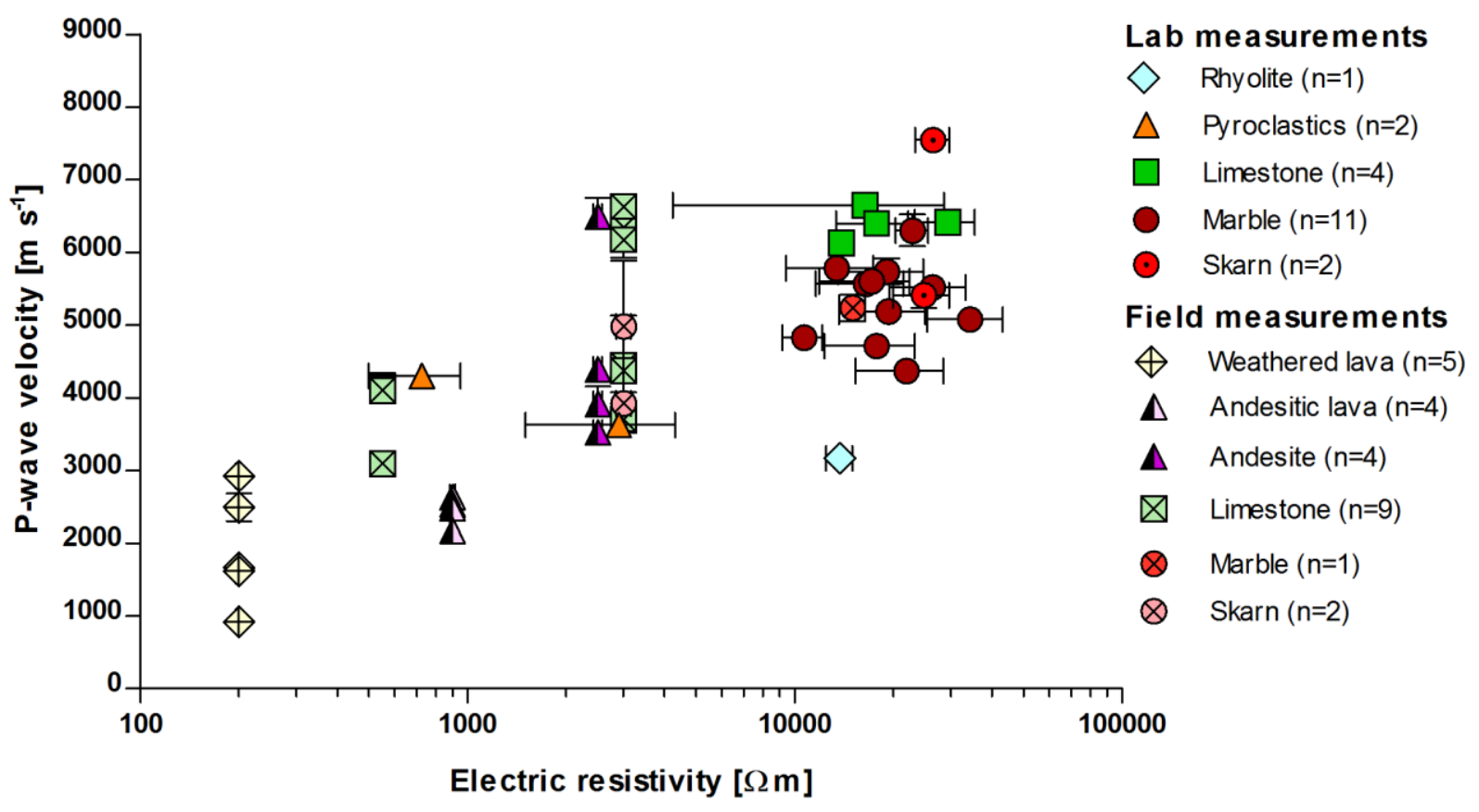

Figure S3: Comparison of electric resistivity and P-wave velocity measurements carried out in the laboratory and in the field. 


\section{Planned investigations on the sample material}

Detailed complementary thin section analysis combined with XRD and XRF measurements will provide information about the mineral assemblage, geochemistry, the intensity of hydrothermal alteration and fluid rock interactions.

Destructive geomechanical tests (e.g. uniaxial and triaxial tests) will be conducted after non-destructive petrophysical

5 measurements in order to evaluate possible stimulation of the basement. Cyclical heating experiments are being conducted to analyse the impact of temperature at reservoir conditions on the mechanical behaviour of the basement rocks. Therefore, representative samples will be thermally treated at temperatures ranging from 105 to $600{ }^{\circ} \mathrm{C}$. Non-destructive petrophysical measurements and destructive uniaxial tests will be carried out before and after each heating cycle. Thin section analysis will allow the identification of temperature induced changes on the microscale. Furthermore, thermotriaxial tests and thermal 10 conductivity measurements with temperatures of up to $200{ }^{\circ} \mathrm{C}$ are intended to transfer the rock properties from outcrop and lab to in-situ reservoir conditions.

Varying degrees of hydrothermal alteration can be identified in the few available borehole core samples from the Los Humeros geothermal field. This results from interaction of the reservoir rocks with neutral to alkaline $\mathrm{Na}-\mathrm{Cl}$ reservoir waters (Izquierdo et al., 2008), plus also localised acid leaching that forms bleached and silificied zones in some wells (Elders et al.,

15 2014). Mineral phases within igneous, intrusive and extrusive rocks are generally unstable in aqueous solutions and are thermodynamically driven towards hydrolysis reactions, resulting in their dissolution and the formation of a range of secondary phases. The presence of geothermal heat together with acidic gases from igneous bodies can speed up hydrolysis reactions and results in significant changes in both the mineralogical composition of the rocks and their physical characteristics.

20 High p/T-experiments are being carried out to investigate hydrothermal driven geochemical changes which could be occurring within the reservoir and to quantify the extent of the consequent dissolution/precipitation reactions. A series of sealed cells have been designed where andesitic material is being reacted with synthetic Los Humeros reservoir water at temperatures of $200-300{ }^{\circ} \mathrm{C}$ and pressures of $200-300$ bar. In particular two types of experiments will be investigated: Closed system batch experiments with a focus on the reaction of andesitic reservoir rocks with hot synthetic geothermal

25 water and open system experiments to investigate the geochemical consequences of a fluid equilibrated with one rock type migrating into another rock type (e.g. simulating processes that could happen when deeply sourced, hot, acidic, Ca-rich water travels up fractures and into the andesites of the geothermal reservoir). The overall objective of the experiments is to simulate reactions occurring within the reservoir zone and to compare the experimental reaction products with what is seen in the borehole core samples.

30 These experiments will be complemented by long term flow through experiments for each key unit (limestone, andesite, granite, basalt). The experiments will run under simulated in-situ conditions (up to supercritical conditions) to study the impact of fluid-rock interactions on permeability, electrical conductivity and on fluid chemistry. 
Beside the extensive geological investigations, thermophysical properties of the reservoir fluids are important key parameters to enhance reservoir understanding and modelling hot geothermal systems with supercritical fluid conditions. Chemical data of fluid samples taken from wells at the Los Humeros geothermal field during previous studies (Tello, 2005; Bernard et al., 2011; Elders et al., 2014) will be combined with ongoing thermophysical fluid measurements to quantify the

5 reservoir fluid properties. The aim is to evaluate a possible impact of dissolved substances (e.g. silica and dissolved borate salts) on the thermophysical properties of the fluids and the physo-chemical processes that occur on the micro scale.

The detailed petrophysical characterization performed in the analogues will be upscaled to model the subsurface reservoir rock properties and simulate fluid flow and heat transport in these geothermal systems. Considering the extreme 10 heterogeneity of properties within same rock types, stochastic modelling approach is used. Monte Carlo based stochastic approaches enable the quantification of uncertainties in the output model as a result of uncertainties in the input parameters.

\section{Preliminary results of the fluid properties}

Available chemical data of reservoir fluids from previous studies (e.g., Tello, 2005; Bernard et al., 2011; Elders et al., 2014) indicate that compositions are rather variable, showing aqueous mixtures of dissolved chlorite, carbonate, and sulfate salts as

15 well as of silica and boron. In contrast, total dissolved solid (TDS) content is low at around $1 \mathrm{~g} \mathrm{~kg}^{-1}$ of solution on average and at about $4 \mathrm{~g} \mathrm{~kg}^{-1}$ at maximum. The latter TDS content would correspond to an equivalent $\mathrm{NaCl}$ concentration of approximately $0.07 \mathrm{~mol} \mathrm{l}^{-1}$, which is also reflected by the highest electrical fluid conductivity reported (i.e. $7 \mathrm{mS} \mathrm{cm}^{-1}$ at $\left.25^{\circ} \mathrm{C}\right)$. Silica $\left(\mathrm{SiO}_{2}\right)$ content is typically around $0.3 \mathrm{~g} \mathrm{~kg}^{-1}$ of solution on average, and about $1 \mathrm{~g} \mathrm{~kg}^{-1}$ at maximum. A striking feature of some of the fluid samples is an unusually high boron content of up to $3.6 \mathrm{~g} \mathrm{~kg}^{-1}$ of solution, presumably present as 20 dissolved borate salts (Bernard et al., 2011).

Given the low TDS of the majority of the reservoir fluids, it can be implied that their thermophysical liquid phase properties will closely match those of pure water properties at given pressure and temperature conditions, provided that the fluid state is subcritical. Consequently, the respective IAPWS formulations for ordinary water substance (IAPWS R12-08, 2008; IAPWS R15-11, 2011; IAPWS R6-95, 2016) could be reliably used in reservoir models or for reservoir and plant engineering 25 purposes. This should apply for viscosity, density, sonic velocity, thermal conductivity, and specific heat as indicated in Fig. 7 for the aqueous $0.07 \mathrm{M} \mathrm{NaCl}$ fluid equivalent mentioned previously (e.g., Hoffert et al., 2015). Viscosity is the physical property most likely to be affected by TDS content, and the departure from pure water properties is estimated to be a maximum of +1.2 , and is followed by density $(+0.24 \%)$, sonic velocity $(+0.18 \%)$, thermal conductivity $(-0.13 \%)$, and specific heat $(-0.31 \%)$, respectively, at $25{ }^{\circ} \mathrm{C}$ reference temperature and ambient pressure. Electrical fluid conductivity, in 30 contrast, is significantly affected by TDS content and consequently shows variations between samples ranging from ca. 0.1 
to $7 \mathrm{mS} \mathrm{cm}^{-1}$ at $25^{\circ} \mathrm{C}$. A potential effect of silica and dissolved borate salts on the thermophysical fluid properties remains to be evaluated.

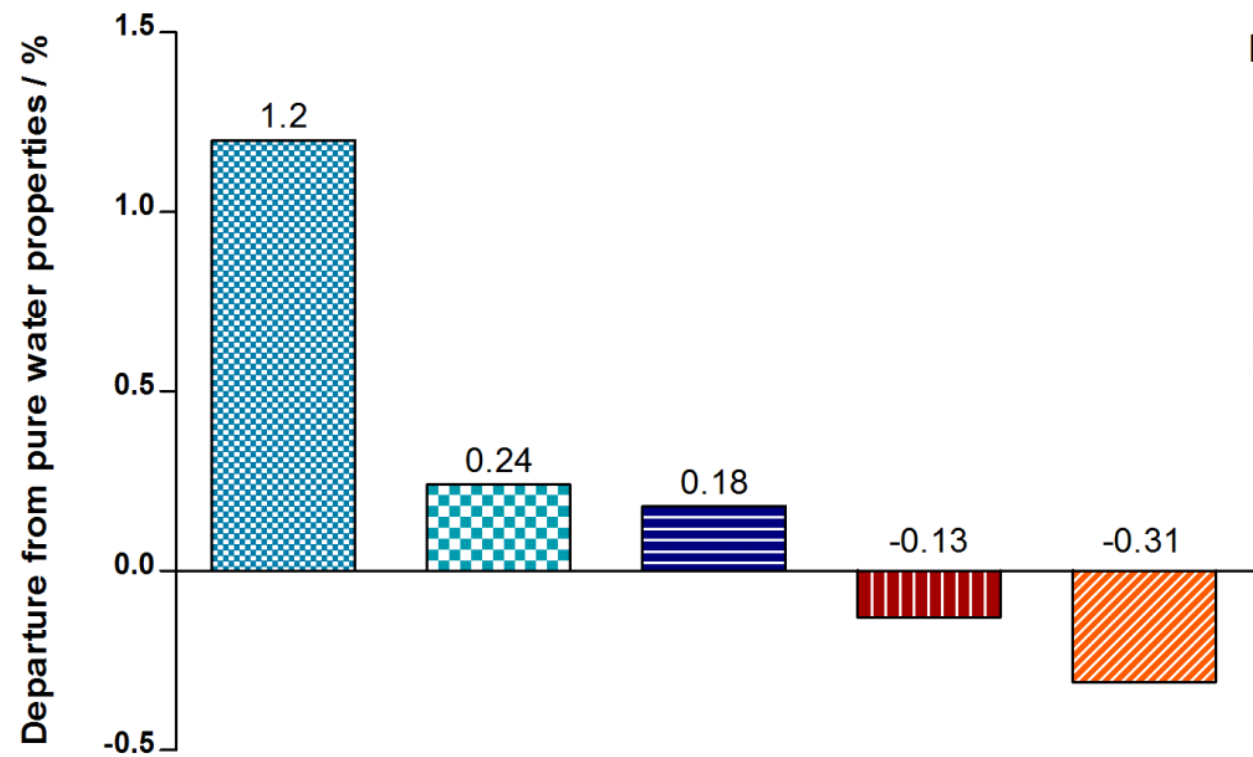

Figure S4: Physical properties of an aqueous $0.07 \mathrm{M} \mathrm{NaCl}$ fluid equivalent for Los Humeros geothermal field relative to 5 pure water indicated as percent deviation at $25{ }^{\circ} \mathrm{C}$ reference temperature and ambient pressure.

\section{References supplementary material}

Bernard, R., Taran, Y., Pennisi, M., Tello, E., Ramirez, A.: Chloride and Boron behavior in fluids of Los Humeros geothermal field (Mexico): A model based on the existence of deep acid brine, Applied Geochemistry, 26, 2064-2073, 2011.

Elders, W.A., Izquierdo-Montalvo, G., Aguilar, A.A., Aguado, R.T., and Armenta, M.F.: Significance of Deep Zones of Intense Bleaching and Silicification in the Los Humeros High-Temperature Geothermal Field, Mexico: Evidence of the Effects of Acid Alteration, GRC Transactions, Vol. 38, 497-502, 2014.

Hoffert, U. and Milsch, H.: Experimental Investigations on the Thermophysical Properties of Synthetic Geothermal Fluids, Proceedings World Geothermal Congress 2015 (Melbourne, Australia 2015), Paper 16030, 2015.

IAPWS R12-08: International Association for the Properties of Water and Steam, Release on the IAPWS Formulation 2008 for the Viscosity of Ordinary Water Substance, 2008. 
IAPWS R15-11: International Association for the Properties of Water and Steam, Release on the IAPWS Formulation 2011 for the Thermal Conductivity of Ordinary Water Substance, 2011.

IAPWS R6-95: International Association for the Properties of Water and Steam, Revised Release on the IAPWS Formulation 1995 for the Thermodynamic Properties of Ordinary Water Substance for General and Scientific Use, 2016.

5 Izquierdo Montalvo, G., Aragón Aguilar, A., Portugal Marín, E., and Arellano Gómez, V.: Hydrothermal Mineralogy as a Tool to Define the Thermal Aquifer of Los Humeros Geothermal Field, Mexico, GRC Transactions, 32, 219-224, 2008.

SGM: CARTA GEOLÓGICO - MINERA, Ciudad de Mexico, E14-2, EDU DE MEX, TLAX, D.F., PUE., HGO. Y MOR., Servicio Geológico Mexicano, first edition, 2002a.

SGM: CARTA GEOLÓGICO - MINERA, Veracruz, E14-3, Veracruz, Puebla y Tlaxcala, first edition, $2002 \mathrm{~b}$.

10 Tello, H. E.: Estado de equilibrio soluto-mineral y saturación de minerales de alteración en fluidos geotérmicos de alta temperature, Facultad de Ingeniería, UNAM, PhD Thesis, 2005. 